\title{
Succession of macrobenthos in a created salt marsh
}

\author{
Lisa A. Levin ${ }^{1, *}$, Drew Talley ${ }^{1}$, Gordon Thayer ${ }^{2}$ \\ ${ }^{1}$ Marine Life Research Group, Scripps Institution of Oceanography, La Jolla, California 92093-0218, USA \\ ${ }^{2}$ National Marine Fisheries Service, Beaufort Laboratory, 101 Pivers Island, Beaufort, North Carolina 28516-9722, USA
}

\begin{abstract}
Early succession of macrofauna was examined over several years in a created Spartina alterniflora marsh located on the Newport River Estuary, North Carolina, USA. Epifauna and infaunal community structure and composition were compared at 2 elevations in plots planted with $S$. alterniflora, plots left bare of vegetation and vegetated plots in a nearby natural S. alterniflora marsh. No significant successional differences were observed between vegetated and unvegetated sediments in the created marsh. The earliest stages of colonization involved recruitment by opportunistic estuarine polychaetes: Streblospio benedicti, Capitella spp. and Polydora cornuta. Capitella spp. dominated the macrofauna a month after marsh creation, but thereafter $S$. benedicti was the most abundant species. During the first few years, the artificial marsh retained early successional characteristics, with $S$. benedicti, Capitella spp. and turbellarians accounting for 75 to $95 \%$ of the total macrofauna. Fiddler crabs were common epifaunal colonists. After $4 \mathrm{yr}$, species nchness increased and dominance by the early colonists diminished. Taxa lacking planktonic larvae and swimming adults were particularly slow to recover in the created marsh, but accounted for over $25 \%$ of the infauna by Year 4 . Oligochaetes, which comprised over $50 \%$ of the fauna in the natural marsh, remained absent or rare in the artificial system throughout the study. Infaunal recovery appears to be more rapid in lower than upper marsh elevations. Although macrofaunal densities and species richness of sediments in the lower created marsh came to resemble those of the natural marsh within 6 mo, specles composition and faunal feeding modes did not. These observations suggest there may be significant functional differences between young artificial marshes and older natural marshes. Consıderation of the timing of marsh creation, marsh configuration, continuity with natural marshes, seeding of taxa with poor dispersal, and attention to species habitat requirements are recommended to accelerate infaunal colonization of created Spartina marshes.
\end{abstract}

KEY WORDS: Restoration Macrofauna - Colonization Mitigation Community structure Life history. Epifauna. Spartina alterniflora-Dispersal. Oligochaetes Polychaetes Capitella spp.

\section{INTRODUCTION}

Disturbance is a ubiquitous feature of shallow-water marine environments. While natural events such as storms, ice scour, or detritus deposition create disturbed patches in intertidal habitats, human activities often create new types of disturbance (Hall et al. 1994). In the coastal zone, habitat loss or degradation is increasingly mitigated by restoration or creation of new habitat. In fact, mitigation through the U.S. Army Corps of Engineers authorities and restoration of habitats required by various U.S. legislative acts (e.g Superfund, Oil Pollution Act) have generated increased

•E-mail:1levin@ucsd.edu levels of coastal habitat mitigation, restoration and enhancement. Man-made systems typically resemble heavily disturbed habitats immediately after their creation because they contain few inhabitants and substrates may differ from natural conditions.

In the case of salt marshes, restoration efforts involving grading of upland soils or dredge spoils to tidal elevation and planting of cordgrass (Spartina spp.) or pickleweed (Salicornia spp.) have been underway for decades (Race \& Christie 1982, Broome et al. 1988, Zedler 1988). Yet the information required to assess successful recovery of marsh function as recommended by the National Wetlands Policy Forum (1988) is collected only rarely. This is especially true for salt marsh sediments and infauna. Many of the faunal studies reported to date have been conducted in Spartina 
alterniflora marshes of North Carolina, USA (Cammen 1976, Sacco et al. 1987, 1994, Moy \& Levin 1991). These investigations examined infaunal communities in man-made marshes 1 to $17 \mathrm{yr}$ after their creation. Differences in diversity and species abundance between artificial and natural systems were reported, but marsh age was not necessarily a good predictor of how closely the man-made system resembled nearby natural ones. Elevation, substrate type, and natural levels of disturbance appeared more important. For example, after only a few years, the infauna of a small created marsh, located in shifting sandy sediments swept by tidal currents, came to resemble that of its natural counterpart which was also heavily disturbed, while the infauna of a muddy 13 yr old system still differed in abundance and feeding modes from the adjacent natural marsh (Sacco et al. 1994)

Created (man-made) wetlands range in size from small pocket marshes around $100 \mathrm{~m}^{2}$ (e.g. Sacco et al. 1994) to large areas encompassing entire lagoons (City of Carlsbad 1990). Where extensive dredging or grading is involved, the system can be viewed as an extraordinarily large colonization experiment, with the earliest recruits encountering substrate bare of other animals. Most studies of infaunal colonization have focused, by necessity, on small-scale disturbance (e.g. Gallagher et al. 1983, Levin 1984, Smith \& Brumsickle 1989, reviewed in Hall et al. 1994), though seasonal succession has been evaluated over larger areas (e.g. Trueblood et al. 1994). Newly created marshes offer an exciting opportunity to evaluate succession in much larger patches, where the sediment disturbance covers one or more acres. Factors that might affect infaunal colonization rates and colonist composition in artificial marsh sediments include the size of the habitat and its proximity to or contact with source populations (Connel \& Keough 1985, Sousa 1985), vegetation characteristics (Rader 1984, Lana \& Guiss 1992), and soil properties such as grain size or organic matter content (Moy \& Levin 1991, Sacco et al. 1994).

The study presented here examines the early succession of a 2.2 acre (0.9 ha), man-made marsh located on the Newport River in Morehead City, North Carolina. Infaunal assemblages colonizing newly graded sediments, either planted with Spartina alterniflora, or left bare, are compared to assemblages in an adjacent natural S. alterniflora marsh. We ask whether distinct successional stages (a sequence of assemblages that differ in taxonomic, trophic, and reproductive characteristics) can be identified for the macrofauna of created systems that might be useful in tracking development of artificial marshes. Identification of such stages and their duration would help researchers and resource managers establish criteria for marsh restoration success and a temporal framework for monitoring. We examine the feeding modes and life-history traits of colonizing species in an attempt to identify some of the factors controlling succession in salt marsh systems (i.e. food requirements vs colonization potential). Knowledge of mechanisms underlying succession should lead to improved methods for marsh creation and restoration.

\section{METHODS AND SITE CHARACTERISTICS}

Marsh creation and experimental design. This study was carried out at the man-made Port Marsh and an adjacent natural Spartina alterniflora marsh located in the Newport River estuary near Morehead City, North Carolina $\left(34^{\circ} 45^{\prime} \mathrm{N}, 76^{\circ} 40^{\prime} \mathrm{W}\right.$ ) (Fig. 1), approximately $3 \mathrm{~km}$ from the Atlantic Ocean. The Port Marsh experimental site was created in June 1990 by grading a 2.2 acre area of dry dredge spoil to sea level and planling the entire area (except for several plots and walk-

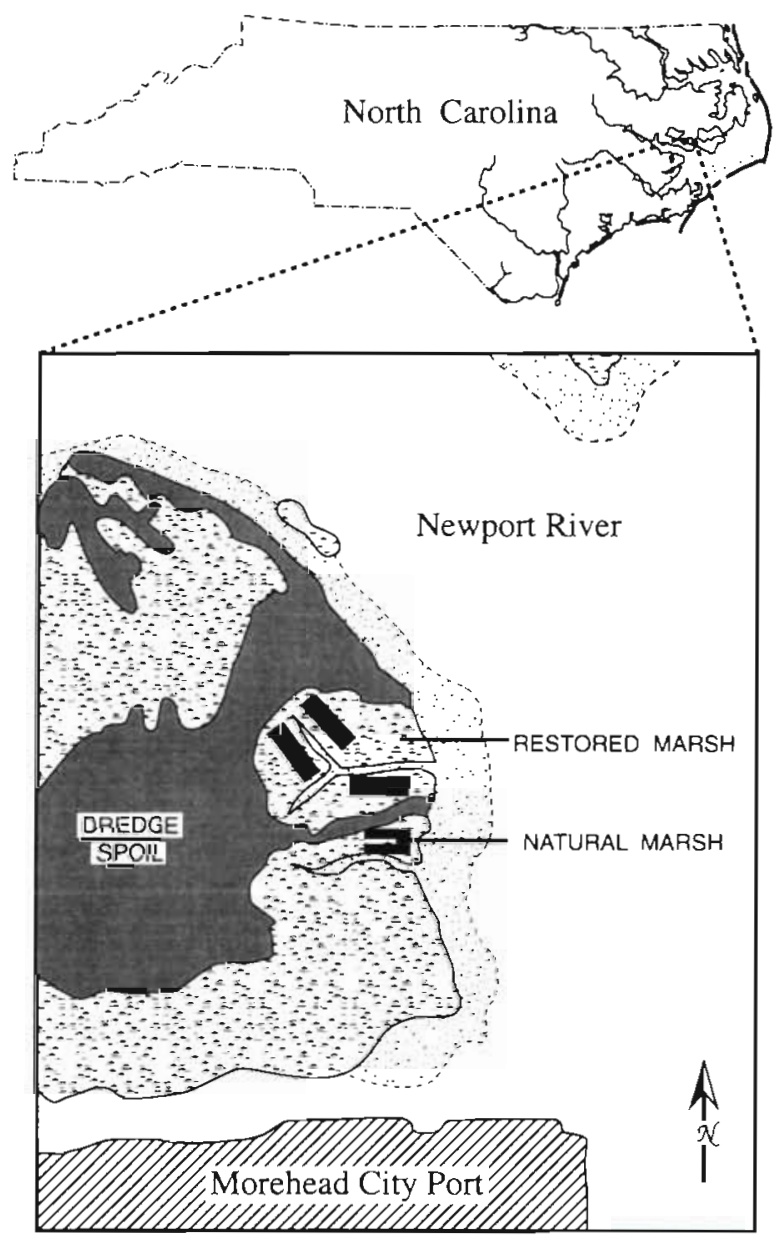

Fig. 1. Location and layout of the created (restored) and natural Port Marsh study sites in the Newport River Estuary near Morehead City, North Carolina, USA 
ways described below) with $S$. alterniflora at a density of 9 culms $\mathrm{m}^{-2}$. Elevation of the created Spartina marsh ranged from 0.58 to $1.03 \mathrm{~m}$ above mean low water (MLW). The site was bordered on 2 sides by natural $S$. alterniflora marsh. An adjacent lower lying area contamed shrub vegetation (wax myrtle, groundsel-tree, red cedar and willow) while the upper terrestrial margin consisted of sparsely vegetated dry sandy dredge material. A small Y-shaped creek was constructed through the center of the marsh. The Port Marsh was largely isolated from the adjacent marshes by an elevated band of brush-covered sediment and oyster shells. The natural marsh to the south was used as a reference site (Fig. 1)

Prior to planting with Spartina alternuflora the study area was divided into 3 expermental blocks $(7 \times 40 \mathrm{~m})$, one along each arm of the channel (Fig. 1) Each block contained ten $2 \times$ $7 \mathrm{~m}$ treatment plots and nine $2 \times 7 \mathrm{~m}$ walkways separating the plots. The plots were orlented across elevation gradients. Upper and lower regions of each plot $(2 \times 1 \mathrm{~m})$ were marked with short PVC pipe. These differed in elevation by $\sim 20 \mathrm{~cm}$, with 'upper' and 'lower' sites 37 and $57 \mathrm{~cm}$ below mean high water, respectively.

The entire experiment consisted of 10 treatments including controls, cultivated solls, varlous organic enrichments and inorganic $N$ additions. Each treatment was replicated 3 times (one $2 \times 7 \mathrm{~m}$ plot in each of 3 blocks) (Fig. 1). Here we report on 2 of the treatments, unvegetated sediments left bare and sed.ments planted with Spartina alterniflora, but receiving no other additions (Flg. 2A, B) These 2 treatments are discussed separately because they represent typical restoration approaches in contrast to the others in which sediments were cultivated by rototiller and amended with organic matter (S. Broome unpubl.). Two control blocks were establıshed at comparable tidal elevations in the $S$. alterniflora marsh 50 to $100 \mathrm{~m}$ to the south (Fig 2C) for comparison of the man-made marsh to a natural system.

Soil and vegetation characteristics. Particle sizes at marsh initiation (June 1990) were substantially finer in the natural marsh $142 \%$ silt/clay) than in the experimental plots $(3 \%$ silt/clay) (S. Broome unpubl. data) Four years later (June 1994), particle sizes in sediments of the created marsh had become much finer Surface sediments of the planted treatments
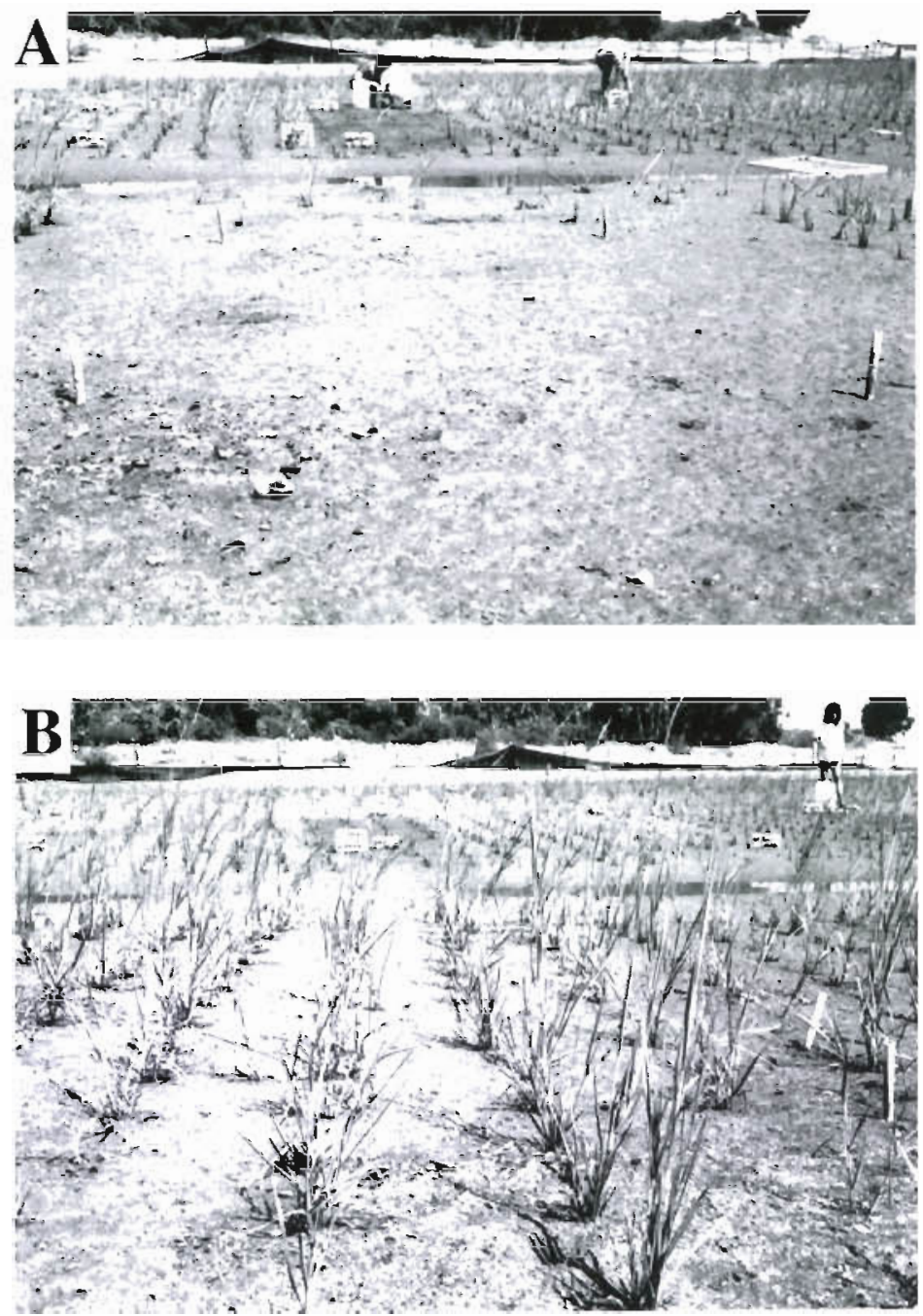

C

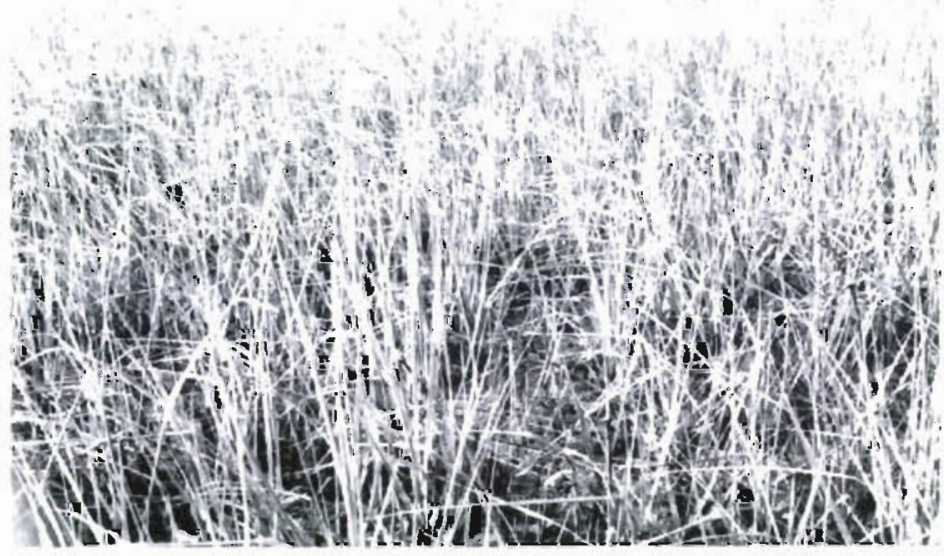

Fig 2 Photographs of (A) unplanted treatment (1n foreground) and (B) planted treatments withın the created Port Marsh Photos were taken Sept 17, 1990, 3 mo aftei marsh cieation (C) Spartuna altermflora in the adjacent natural marsh in June 1990 
( 0 to $2 \mathrm{~cm}$ ) were $47 \%$ silt/clay at lower elevations and $32 \%$ silt/clay at upper elevations. Comparable values for the natural marsh in 1994 were $75 \%$ silt/clay at lower elevations and $56 \%$ silt/clay at upper elevations (C. Currin unpubl data).

In September 1991 (15 mo after the marsh was planted), sediment organic matter (OM) content was higher in the natural marsh $(15.3 \pm 0.8 \%$ at 0 to $1 \mathrm{~cm}$ and $11.9 \pm 0.08 \%$ at 4 to $5 \mathrm{~cm}$ ) than in the unplanted treatment $(1.9 \pm 0.2 \%$ at 0 to $1 \mathrm{~cm}$ and $2.5 \pm 0.5 \%$ at 4 to $5 \mathrm{~cm})$ or in the planted treatment $(2.4 \pm 0.3 \%$ at 0 to $1 \mathrm{~cm}, 1.8 \pm 0.3 \%$ at 4 to $5 \mathrm{~cm}$ ). By June 1994 , sediment $O M$ content ( 0 to $2 \mathrm{~cm}$ ) in the planted treatment had increased, but remained low ( $2.8 \pm 0.7 \%$ at low elevations and $4.6 \pm 1.7 \%$ at upper elevation) relative to the natural marsh $(6.8 \pm 1.1 \%$ at low elevations and $8.3 \pm$ $0.9 \%$ at upper elevation) (C. Currin unpubl. data).

Nitrogen fixation rates were about $2 \times$ higher in the planted and unplanted plots than in the natural marsh over the first few years of marsh existence. This was due mainly to greater abundance of cyanobacteria in the created marsh (C. Currin unpubl.). Stable isotopic analyses suggested that nitrogen fixers were an important part of epifaunal diets in the transplanted marsh (Currin et al. 1995).

Spartina alterniflora growth in the planted treatment was rapid. However, during 1991 and 1992, aboveground $S$. alterniflora biomass (307 to $472 \mathrm{~g} \mathrm{~m}^{-2}$ ) was half that of natural marsh $S$. alterniflora $(649$ to $858 \mathrm{~g}$ $\mathrm{m}^{-2}$ ), while stem densities ( 189 to 280 stems $\mathrm{m}^{-2}$ ) were $2 / 3$ those of the natural marsh (262 to 411 stems $\mathrm{m}^{-2}$ ). By 1993, biomass $\left(777 \pm 146 \mathrm{~g} \mathrm{~m}^{-2}\right)$ and stem densities $\left(364 \pm 37\right.$ stems $\left.\mathrm{m}^{-2}\right)$ in the planted treatment did not differ from those in the natural marsh $\left(858 \pm 38 \mathrm{~g} \mathrm{~m}^{-2}\right.$, $413 \pm 21$ stems $\mathrm{m}^{-2}$ ). The unvegetated plots remained bare of vegetation until 1993 (S. Broome unpubl. data). During 1994, the planted treatment aboveground $S$. alterniflora biomass $\left(1094 \pm 124 \mathrm{~g} \mathrm{~m}^{-2}\right)$ and stem densities $\left(444 \pm 35\right.$ stems $\left.\mathrm{m}^{-2}\right)$ were twice those of the natural marsh (547 $\pm 72 \mathrm{~g} \mathrm{~m}^{-2} ; 226 \pm 28$ stems $\mathrm{m}^{-2}$ ) (S. Broome unpubl. data).

Faunal sampling. Sediments were sampled for infauna with a cylindrical push core $(4.8 \mathrm{~cm}$ diameter $)$ inserted to a depth of $6 \mathrm{~cm}$. On each sampling date, 4 replicate cores were taken from upper and lower elevations within each experimental plot (total of 8 samples per plot, or 24 samples per treatment). The adjacent natural marsh was sampled concurrently by taking 6 cores from both upper and lower elevations of each plot from both blocks (total of 24 samples). Samples were collected from experimental plots and the natural marsh at $1 \mathrm{wk}$ (Jun 1990), 1 mo (Jul 1990), 3 mo (Sep 1990), 6 mo (Dec 1990), 12 mo (Jun 1991), 18 mo (Dec 1991), 22 mo (Apr 1992), and 27 mo (Sep 1992) following marsh creation. The planted treatment and the natural marsh also were sampled 47 mo (May 1994) and 52 mo (Oct 1994) after marsh creation. After the 18 mo sampling, sampling dates were shifted to spring and fall to coincide with periods of maximal recruitment for the most common infaunal species in the region (Watzin 1986, Levin \& Huggett 1990, Levin unpubl. data).

Each infaunal core was split into 2 vertical fractions ( 0 to $2 \mathrm{~cm}$ and 2 to $6 \mathrm{~cm}$ ), and preserved unsieved in a $10 \%$ formalin-seawater solution buffered with sodium phosphate. Preserved sediment samples were stained with rose bengal and washed in the lab through a $300 \mu \mathrm{m}$ sieve to retain macrofauna. Macrofauna were sorted and identified to the lowest taxon possible, counted, and stored in vials of approximately $70 \%$ ethanol. Reproductive activity and in some cases trophic mode of brooded larvae were documented. Meiofaunal taxa such as nematodes, ostracods, copepods and foraminifera were not counted.

Epifaunal counts were made in the field on the same schedule as infaunal sampling for 27 mo after marsh initiation. Animals visible on the sediment surface (molluscs and crustaceans), as well as crab burrows, were identified and counted within two $0.0625 \mathrm{~m}^{2}$ quadrats placed randomly in planted and unplanted plots at upper and lower elevations in each plot sampled for infauna. In the natural marsh, quadrats were placed within several meters of the plots sampled for infauna, at comparable elevations.

Data analyses. JMPTH software (SAS Institute, Inc.) was used to examine effects of elevation and treatment on species abundances, species richness, composition, development modes and lifestyles. Blocks were the experimental units across which treatments were replicated, not the individual cores. Values for cores ( $n=4$ upper elevation and $n=4$ lower elevation) were averaged to obtain a block mean for each treatment. The means for each created marsh block ( $\mathrm{n}=3$ blocks) were compared to the means for the natural marsh blocks ( $\mathrm{n}=2$ blocks) by $t$-tests. Upper and lower elevations were treated separately in analyses of abundance, species richness, and feeding modes. Where elevation is not indicated, statistical values are for upper and lower elevations combined. Comparisons of treatment means within times were made by $t$-tests. Time itself could not be examined as a variable (e.g via ANOVA) due to non-independence of sampling dates. Percentage data generated for vertical distributions, feeding modes and development modes were arcsin-transformed prior to statistical analyses and back-transformed for graphical presentation. Because marshes were not replicated in this study, our inferential space is limited to the Port Marsh system.

Feeding modes were evaluated by assigning taxa as surface-deposit feeders, subsurface-deposit feeders or 
carnivores/omnivores based on our previous experience in North Carolina marshes and on published literature (Fauchald \& Jumars 1979, Sacco et. al. 1994). For developmental mode and dispersal analyses, infauna were assigned to 1 of 4 categories: those with planktotrophic larvae, those with lecithotrophic larvae, direct developers without an adult swimming stage, or direct developers with an adult swimming stage. Assignments were made based on the authors' familiarity with reproduction in the resident species and on direct observations. For both feeding- and development-mode analyses, the proportional representation of each mode was calculated for all the individuals sampled from each plot $(\mathrm{n}=3$ planted plots, $\mathrm{n}=3$ unplanted plots, $n=2$ natural marsh plots). Means for the arcsin-transformed proportions of any specific feeding or development mode were compared between treatments using $t$-tests. Throughout the paper, error terms given are standard error (SE) unless stated otherwise.

\section{RESULTS}

\section{Epifauna}

Epifauna present in the natural marsh included ribbed mussels (Geukensia demissus), oysters (Crassostrea virginica), mud crabs (Panopeus herbstii), littorine snails (Littorina irrorata), mud snails (Nassarius obsoletus), and fiddler crabs (Uca spp.) (Table 1). Since sampling was carried out at low tide, fish and blue crabs were not detected, although they were present at high water.

During the first year of artificial marsh existence, only Uca spp. were present, with crab and burrow densities higher than those observed in the natural marsh (Table 1). During the second year, mud snails (Nassarius obsoletus) colonized, primarily in the unvegetated treatment (Table 1). Mussels, oysters, mud crabs and littorine snails were not detected in the created marsh plots during the 27 mo study period.

\section{Macrofaunal abundance, richness and composition}

Natural marsh (reference site)

Macrofaunal abundances in the natural marsh ranged from 30 to 100 individuals per core (16666 to $60556 \mathrm{~m}^{-2}$ ) at the upper elevation and from 50 to 152 individuals per core (32221 to $84436 \mathrm{~m}^{-2}$ ) at the lower elevation (Fig. 3), Average species richness per block ranged from 9 to 18 species at both elevations (Fig. 4); however, over $80 \%$ of the individuals collected were either oligochaetes (45.3\%), or the spionid polychaete Streblospio benedicti $(35.7 \%)$. Other groups present included members of the polychaete genera Capitella $(3.7 \%)$, Neanthes $(2.0 \%)$, Aphelochaeta $(1.7 \%)$, and Fabricia (1.2\%), turbellarians $(2.0 \%)$, the snail Littorina irrorata $(2.0 \%)$, the tanaid Leptochelia savignyi $(1.6 \%)$, and the bivalve Gemma gemma (1.3\%). The remaining taxa (all $<1 \%$ ) included the polychaetes Manayunkia estuarina, Polydora cornuta (= ligni), Eteone sp., Heteromastus sp., Notomastus sp., and Mediomastus sp., the bivalve Macoma sp., the gastropod Nassarius obsoletus, fiddler crabs (Uca spp.), isopods and amphipods. A total of 29 species were collected in the natural marsh during the entire study. Upper and lower elevations did not exhibit significant differences in macrofaunal species richness, and abundance differences between elevations were observed on only 1 of 10 sampling dates (July 1990).

Initial colonization events in the created marsh: 0 to 3 mo

One week (June 1990): One week after the marsh was established, colonization patterns were essentially identical in the planted and unplanted experimental plots (Figs. 3, 4 \& 5). Macrofauna were present at low densities, $2887 \pm 212 \mathrm{~m}^{-2}$ in the planted plots and $2430 \pm 805 \mathrm{~m}^{-2}$ in the unplanted plots. Elevation had no effect on densities in the unvegetated plots $\left(t_{4}=1.150\right.$. $p=0.314$ ), while low-elevation sites exhibited higher densities of macrofauna than high-elevation sites in planted plots $\left(t_{4}=5.255, p=0.006\right)$. Species richness averaged 4 to 5 species per plot in planted and unplanted treatments at both elevations, significantly lower than the 12 species present in natural marsh plots (Fig 4) (unplanted vs natural. $t_{3}=3.679, \mathrm{p}=$ 0.035; planted vs natural: $t_{3}=3.910, p=0.030$ ).

Initial colonization was by 3 opportunistic polychaete species, Streblospio benedicti (55\%), Capitella sp. $(25 \%)$, and Polydora cornuta $(7 \%$ in the planted plots) (Fig. 5). Proportionately, S. benedicti was better represented in the experimental plots $(55 \%)$ than in the natural marsh $(21 \%)$ (unplanted vs natural: $t_{3}=$ 3.916, $\mathrm{p}=0.030$; planted vs natural: $t_{3}=3.293, \mathrm{p}=$ 0.046 , t-tests on arcsin-transformed block proportions). Other taxa present included the nereid polychaete Neanthes succinea, fiddler crabs Uca spp., and 2 oligochaete individuals

One month (July 1990): After 1 mo, species densities had nearly tripled to $5948 \pm 2224$ individuals $\mathrm{m}^{-2}$ in planted plots and $6180 \pm 2086 \mathrm{~m}^{-2}$ in unplanted plots (Fig. 3). Elevation had no effect on densities. Densities in the planted treatments were significantly lower than in the natural marsh for both upper-elevation $\left(t_{3}=3.023\right.$, 
Table 1. Mean densities ( $\pm 1 \mathrm{SE}$ ) of epifauna present per $0.125 \mathrm{~m}^{2}$ in arti.icial marsh treatments (planted and unplanted) and in an adjacent natural marsh. Sampling dates are shown as month-day-year. Natural marsh $n=4 ;$ planted, unplanted treatments $n=3$

\begin{tabular}{|c|c|c|c|c|c|c|c|c|}
\hline \multirow[t]{2}{*}{$\begin{array}{l}\text { Marsh age } \\
\text { Treatment }\end{array}$} & \multicolumn{2}{|c|}{ Tofal epitauna } & \multicolumn{2}{|c|}{$\begin{array}{c}\text { Fiddler crabs } \\
\text { (Uca spp.) }\end{array}$} & \multicolumn{2}{|c|}{$\begin{array}{c}\text { Mud snauls } \\
\text { (Nassarrus obsoletus) }\end{array}$} & \multicolumn{2}{|c|}{$\begin{array}{c}\text { Oysters } \\
\text { (Crassostrea virginica) }\end{array}$} \\
\hline & Upper & Lower & Upper & Lower & Upper & Lower & Upper & Lower \\
\hline \multicolumn{9}{|l|}{$1 \mathrm{wk}(6-21-90)$} \\
\hline Natural & $17.0 \pm 15.7$ & $8.3 \pm 4.6$ & 0 & 0 & $13.25 \pm 13.25$ & 0 & $0.25 \pm 0.25$ & $4.50 \pm 2.96$ \\
\hline \multicolumn{9}{|l|}{1 mo $(7-25-90)$} \\
\hline Natural & $7.25 \pm 5.62$ & $31.00 \pm 11.73$ & $4.25 \pm 2.66$ & 0 & 0 & $29.25 \pm 12.80$ & 0 & $1.50 \pm 1.50$ \\
\hline Planted & $4.00 \pm 2.31$ & $4.67 \pm 0.67$ & $4.00 \pm 2.31$ & $467 \pm 0.67$ & 0 & 0 & 0 & 0 \\
\hline Unplanted & $5.00 \pm 4.04$ & $500 \pm 1.15$ & $4.67 \pm 4.18$ & $500 \pm 1.15$ & $0.33 \pm 0.33$ & 0 & 0 & 0 \\
\hline \multicolumn{9}{|l|}{3 mo $(9-18-90)$} \\
\hline Natural & $13.25 \pm 1292$ & $16.75=11.84$ & 0 & 0 & $13.00 \pm 1267$ & $1325 \pm 12.92$ & 0 & $1.00 \pm 1.00$ \\
\hline Planted & $7.33 \pm 3.71$ & $1.33 \pm 0.88$ & $7.33 \pm 3.71$ & $1.33 \pm 0.88$ & 0 & 0 & 0 & 0 \\
\hline Unplanted & $2.33 \pm 1.20$ & $0.67 \pm 0.33$ & $2.33 \pm 1.20$ & $0.67 \pm 0.33$ & 0 & 0 & 0 & 0 \\
\hline \multicolumn{9}{|c|}{6 mo $(12-13-90)$} \\
\hline Natural & $9.50 \pm 4.37$ & $21.75 \pm 7.78$ & 0 & 0 & $7.75 \pm 520$ & $1475 \pm 7.86$ & 0 & $3.75 \pm 3.75$ \\
\hline Planted & 0 & 0 & 0 & 0 & 0 & 0 & 0 & 0 \\
\hline Unplanted & 0 & 0 & 0 & 0 & 0 & 0 & 0 & 0 \\
\hline \multicolumn{9}{|c|}{$12 \mathrm{mo}(6-26-91)$} \\
\hline Natural & $875 \pm 7.76$ & $20.25=17.68$ & 0 & 0 & $8.00 \pm 8.00$ & $20.25 \pm 1768$ & 0 & 0 \\
\hline Planted & $8.67 \pm 1.3 .3$ & $16.00+5.51$ & $867 \neq 1.33$ & $16.00=5.51$ & 0 & 0 & 0 & 0 \\
\hline Unplanted & $17.33 \pm 882$ & $6.00 \pm 3.61$ & $17.33=8.82$ & $6.00 \pm 3.61$ & 0 & 0 & 0 & 0 \\
\hline \multicolumn{9}{|c|}{$18 \mathrm{mo}(12-2-91)$} \\
\hline Natural & $1.00 \pm 100$ & $1300=3.92$ & 0 & 0 & $1.00 \pm 1.00$ & $12.25 \pm 457$ & 0 & $0.75 \pm 0.75$ \\
\hline Planted & $0.67 \geq 0.67$ & $1.00=0.58$ & 0 & $0.67 \pm 0.67$ & $0.67 \pm 0.67$ & $0.33 \pm 0.33$ & 0 & 0 \\
\hline Unplanted & $3.00=3.00$ & $13.67 \pm 13.67$ & $3.00 \pm 300$ & 0 & 0 & $13.67 \pm 13.67$ & 0 & 0 \\
\hline \multicolumn{9}{|c|}{$22 \mathrm{mo}(4-16-92)$} \\
\hline Natural & $1.75 \pm 1.1 \mathrm{t}$ & $11.25 \pm 1.97$ & 0 & 0 & 0 & $9.00 \pm 2.52$ & $0.75 \pm 0.75$ & $1.5 \pm 0.96$ \\
\hline Planted & $1.67 \pm 0.88$ & $0.33 \pm 0.33$ & $1.67 \div 0.88$ & $033 \pm 033$ & 0 & 0 & 0 & 0 \\
\hline Unplanted & $1.33 \pm 0.88$ & $1.33 \pm 1.33$ & $1.33 \pm 0.88$ & 0 & 0 & $1.33 \pm 1.33$ & 0 & 0 \\
\hline \multicolumn{9}{|c|}{27 mo $(10-8-92)$} \\
\hline Natural & $17.00 \pm 16.34$ & $3100 \pm 20.42$ & 0 & 0 & $16.75 \pm 16.42$ & $28.75 \pm 21.34$ & 0 & $2.00 \pm 2.00$ \\
\hline Planted & 0 & $1.00 \pm 1.00$ & 0 & 0 & 0 & $1.00 \pm 1.00$ & 0 & 0 \\
\hline Unplanted & $6.67 \pm 3.67$ & $17.33 \pm 16.84$ & $2.00 \pm 1.00$ & $0.33 \pm 0.33$ & $4.67 \pm 4.67$ & $17.00 \pm 17.00$ & 0 & 0 \\
\hline & Mu & sels & Litt & nes & $\begin{array}{l}\text { Muc } \\
\text { Sesâ }\end{array}$ & $\begin{array}{l}\text { crabs } \\
\text { masp }\end{array}$ & Burrow & penings \\
\hline & $\begin{array}{l}\text { Geukens) } \\
\text { Upper }\end{array}$ & $\begin{array}{r}\text { demissus! } \\
\text { Lower }\end{array}$ & Unner & Lower & $\begin{array}{l}\text { ISesa } \\
\text { Upper }\end{array}$ & $\begin{array}{l}\text { ma sp } 1 \\
\text { Lower }\end{array}$ & Upper & Lower \\
\hline $1 w k(6-2)-90$ & & & & & & & & \\
\hline Natural & 0 & $5.25 \pm 1.93$ & $3.25 \pm 2.29$ & 0 & $0.25 \pm 0.25$ & 0 & $28.00 \pm 16.73$ & 0 \\
\hline $1 \mathrm{mo}(7-25-90$ & & & & & & & & \\
\hline Natural & $3.00 \pm 3.00$ & 0 & 0 & $0.25 \pm 0.25$ & 0 & 0 & $28.25 \pm 15.24$ & 0 \\
\hline Planted & 0 & 0 & 0 & 0 & 0 & 0 & $14.33 \pm 9.39$ & $21.67 \pm 9.67$ \\
\hline Unplanted & 0 & 0 & 0 & 0 & 0 & 0 & $1.900 \pm 7.55$ & $3466 \pm 1767$ \\
\hline 3 mo $(9-18-90$ & & & & & & & & \\
\hline Natural & 0 & $2.00 \pm 2.00$ & 0 & 0 & $0.25 \pm 025$ & $0.25 \pm 0.25$ & $12.50=7.22$ & $0.5 \pm 0.29$ \\
\hline Planted & 0 & 0 & 0 & 0 & 0 & 0 & $10.00 \pm 4.73$ & $3.67 \pm 1.45$ \\
\hline Unplanted & 0 & 0 & 0 & 0 & 0 & 0 & $700 \pm 3.51$ & $2.67 \pm 0.33$ \\
\hline 6 mo $112-13-9$ & & & & & & & & \\
\hline Natural & $1.75 \cdot 1.03$ & $2.75 \pm 2.75$ & 0 & 0 & 0 & 0 & $775 \pm 5.42$ & 0 \\
\hline Planted & 0 & 0 & 0 & 0 & 0 & 0 & $7.00=0.00$ & $8.00 \pm 2.89$ \\
\hline Unplanted & 0 & 0 & 0 & 0 & 0 & 0 & $16.00 \pm 6.11$ & $10.00 \pm 3.21$ \\
\hline 12 mo $(6-26-9$ & & & & & & & & \\
\hline Natural & $0.75 \pm 0.48$ & 0 & 0 & 0 & 0 & 0 & $12.75 \pm 9.45$ & $0.25 \pm 0.25$ \\
\hline Flanted & 0 & 0 & 0 & 0 & 0 & 0 & $41.00 \pm 4.93$ & $6967 \pm 10.65$ \\
\hline Unplanted & 0 & 0 & 0 & 0 & 0 & 0 & $53.67 \pm 12.99$ & $7900 \pm 26.31$ \\
\hline $18 \mathrm{mo}(12-2-9$ & & & & & & & & \\
\hline Natural & 0 & 0 & 0 & 0 & 0 & 0 & $10.75 \pm 5.91$ & 0 \\
\hline Planted & 0 & 0 & 0 & 0 & 0 & 0 & $8.00=1.53$ & $1233 \pm 4.37$ \\
\hline Unplanted & 0 & 0 & 0 & 0 & 0 & 0 & $16.00 \pm 6.81$ & $2.33 \pm 1.20$ \\
\hline 22 mo $(4-16-9$ & & & & & & & & \\
\hline Natural & $1.00=0.41$ & $0.75 \neq 0.75$ & 0 & 0 & 0 & 0 & $9.25 \pm 4.27$ & 0 \\
\hline Planted & 0 & 0 & 0 & 0 & 0 & 0 & $23.00 \pm 11.14$ & $7.67 \pm 5.24$ \\
\hline Unplanted & 0 & 0 & 0 & 0 & 0 & 0 & $2400 \pm 8.50$ & $0.33 \pm 0.33$ \\
\hline 27 mо $110-8-9$ & & & & & & & & \\
\hline Natural & $025 \pm 0.25$ & $0.25 \pm 0.25$ & 0 & 0 & 0 & 0 & $800 \pm 5.76$ & 0 \\
\hline Planted & 0 & 0 & 0 & 0 & 0 & 0 & $13.33 \pm 5.78$ & $3.00 \pm 2.52$ \\
\hline Unplanted & 0 & 0 & 0 & 0 & 0 & 0 & $36.00 \pm 19.29$ & $133 \pm 0.67$ \\
\hline
\end{tabular}



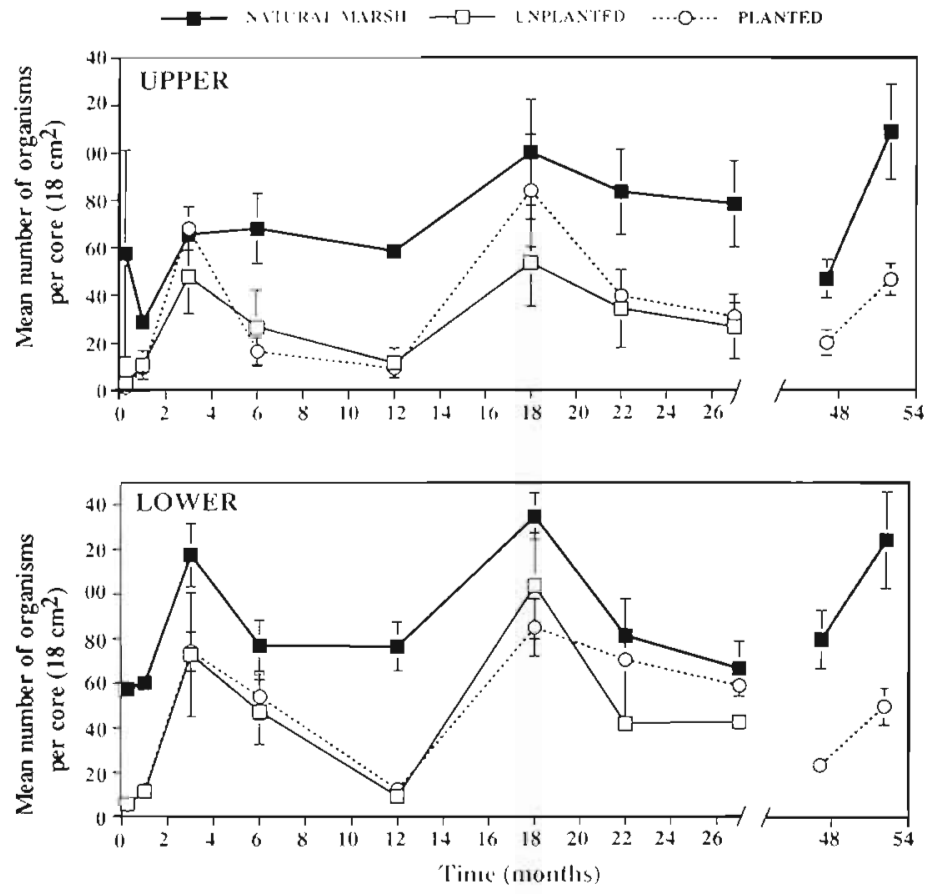

Fig. 3. Macrofaunal densities in the created marsh in planted and unplanted treatments and in the natural marsh control plots at upper (37 $\mathrm{cm}$ below mean high water) and lower (57 $\mathrm{cm}$ below mean high water) elevations. Values are mean $\pm 1 \mathrm{SE}$ species per plot at both upper and lower elevations, but was still lower than the natural marsh in the planted (upper: $t_{3}=2.952, \mathrm{p}=0.060$ i lower: $t_{3}=3.587, \mathrm{p}=0.037$ ) and unplanted plots (upper. $t_{3}=2.956, \mathrm{p}=0.055 ;$ lower $t_{3}=3.133, \mathrm{p}=0.052$ ) (Fig. 4). Species composition was similar in both experimental treatments, but differed from that of the natural marsh. Over 55 to $65 \%$ of all specimens collected were Streblospio benedicti, with Capitellaspp. and turbellarians each accounting for most of the remaining individuals (Fig. 5). In the natural marsh $S$. benedicti accounted for only $37 \%$ of total macrofauna. Densities of the polychaetes $S$. benedicti, Neanthes succinea, and Polydora cornuta and of turbellarians were comparable to those in the natural marsh. However, in the planted treatment Capitella spp. densities were higher $\left(t_{3}=3.144, \mathrm{p}=0.051\right)$ and oligochaete densities were significantly lower $\left(t_{3}=16.589, \mathrm{p}=0.0005\right)$ than those in the natural marsh. In the unplanted treatment Capitella spp. densities did not differ significantly from the natural marsh $\left(t_{3}=1.663, \mathrm{p}=0.195\right)$, while oligochaete densities were lower $\left(t_{3}=16.531\right.$, $p=0.0005$ )

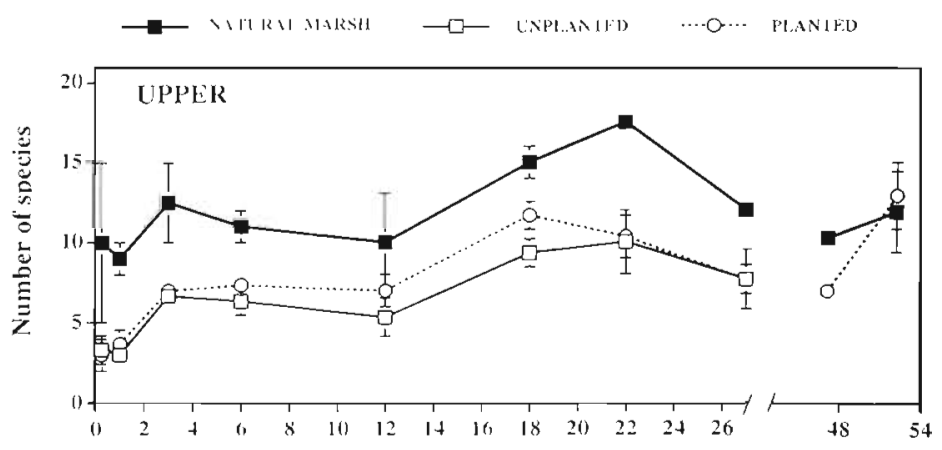

$p=0.057)$ and lower-elevation sites $\left(t_{3}=8.729\right.$, $\mathrm{p}=0.003$ ) (Fig. 3). Densities in the unplanted plots were significantly less than natural levels only at the lower elevation $\left(t_{3}=10.025, p=0.002\right)$. Species richness remained low with an average of 4 species present in each plot for both treatments (Fig. 4). Capitella spp. dominated unplanted $(70 \%)$ and planted plots (64\%) relative to the natural marsh (21\%). Capitella spp. densities in the artificial treatments were higher than in the natural marsh (unplanted vs natural: $t_{4}=4.046, \mathrm{p}=0.027$; planted vs natural: $t_{4}=2.700$, $p=0.074)$. Most of the remaining individuals present were Streblospio benedicti $(21 \%$ in planted plots, $34 \%$ in unplanted plots). Oligochaetes, which comprised $62 \%$ of the natural marsh macrofauna, were conspicuously absent from the planted treatment and only a single individual was present in the unplanted plots

Three months (September 1990): Three months after marsh initiation, densities in the planted $\left(39672 \pm 5096 \mathrm{~m}^{-2}\right)$ and unplanted $\left(35760 \pm 14215 \mathrm{~m}^{-2}\right)$ treatments did not differ significantly from natural marsh densities (51025 \pm $5758 \mathrm{~m}^{-2}$ ). Elevation had no effect on macrofaunal densities in either vegetated or unvegetated treatments. Species richness rose to 7 to 8

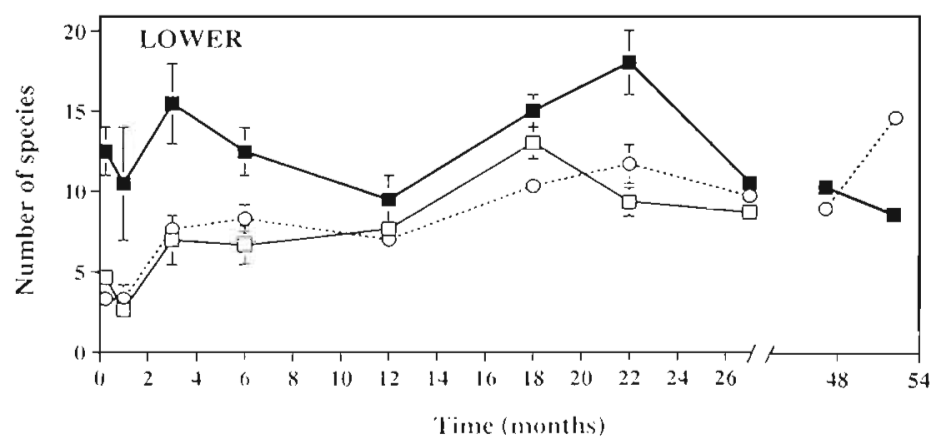

Fig. 4. Species richness in the created marsh in planted and unplanted treatments and in the natural marsh control plots at upper $(37 \mathrm{~cm}$ below mean high water) and lower $(57 \mathrm{~cm}$ below mean high water) elevations. Values are mean $\pm 1 \mathrm{SE}$ and are based on analysis of fauna in an area $72 \mathrm{~cm}^{2} \times 6 \mathrm{~cm}$ deep (4 cores), except for 47 and 52 mo data, where analyses are based on an area $54 \mathrm{~cm}^{2} \times 6 \mathrm{~cm}$ deep ( 3 cores) 

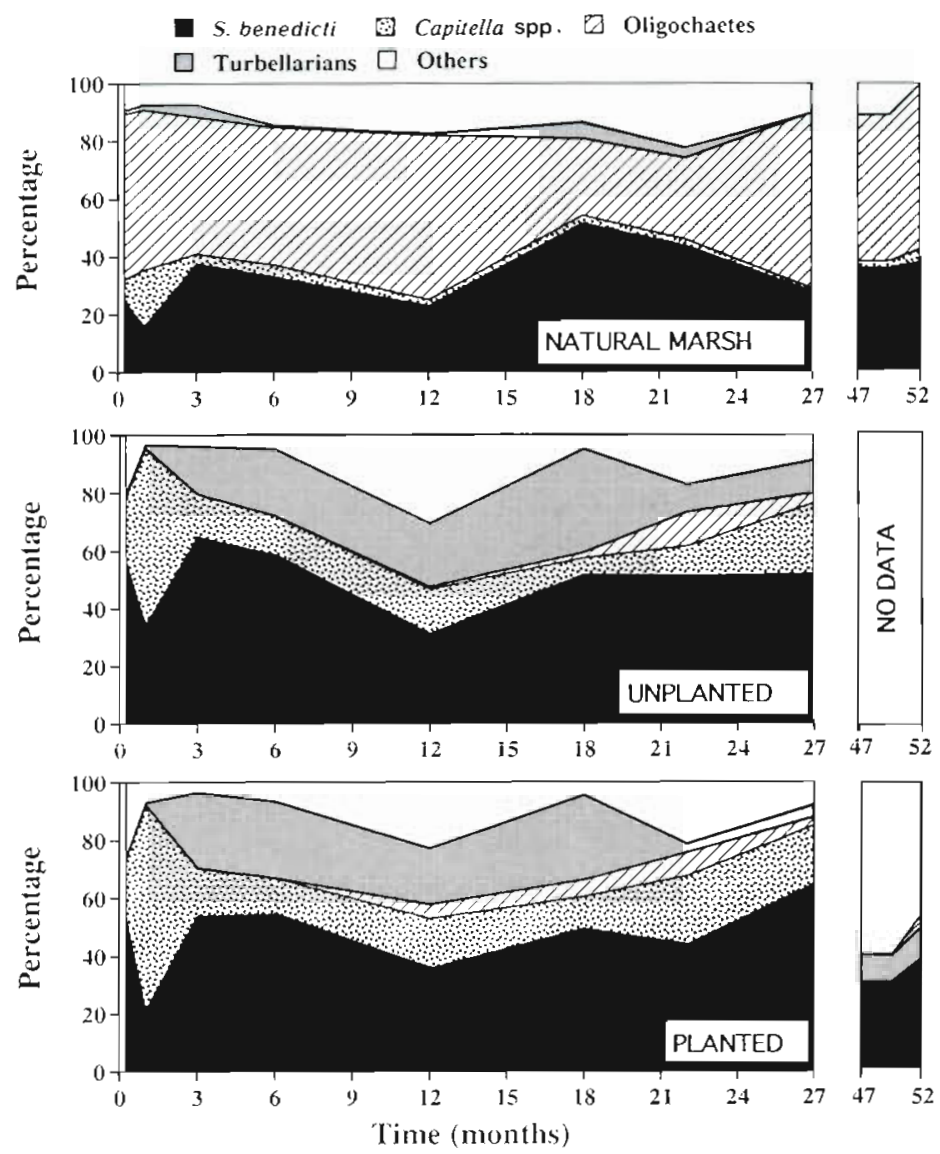

Fig. 5. Proportional representation of dominant taxa over time in the created marsh in planted and unplanted treatments and in adjacent natural marsh plots

Later colonization events: 6 mo (December 1990) to 27 mo (October 1992)

Macrofaunal densities did not differ between planted and unplanted treatments during any of the sampling periods between December 1990 and October 1992 (Fig. 3). During this period densities in the experimental plots ranged from $5717 \mathrm{~m}^{-2}$ to $46739 \mathrm{~m}^{-2}$. There was no tendency for densities to increase over time, nor was there clear evidence of seasonality (Fig. 3). During this period the lowest densities were observed in June 1991 (12 mo after initiation) and the highest in December 1991 (18 mo after initiation).

Elevation had no effect on macrofaunal densities in the natural marsh or the unvegetated plots (in all cases $p \geq 0.18$, $t$-tests comparing upper and lower elevations, calculated for each of 7 dates). However, in the planted treatment macrofaunal densities were greater at lower than upper elevations on 2 of 5 sampling dates, at 6 mo $\left(t_{4}=3.280, \mathrm{p}=0.031\right)$ and $27 \mathrm{mo}\left(t_{4}=3.486, \mathrm{p}=0.025\right)$ (Fig. 3) Between December 1990 and October 1992 macrofaunal densities in the natural marsh ranged from $37186 \pm 2741 \mathrm{~m}^{-2}$ to $64702 \pm 9073 \mathrm{~m}^{-2}$ Densities in the created marsh were significantly lower than in the natural marsh only part of the time, and only for selected treatments. This was true at the 6 mo sampling for upper elevation vegetated plots $\left(t_{3}=3.921, \mathrm{p}=0.030\right)$, at the 12 mo sampling for vegetated and unvegetated treatments, upper and lower elevations (all $t_{3} \geq 4.962, p \leq 0.016$ ), and at the 22 mo sampling for the lower elevation, unvegetated plots $\left(t_{3}=16.567, \mathrm{p}=0.0005\right)$.

The vegetated and unvegetated treatments did not exhibit significant differences in species richness (Fig. 4). Between 6 and 18 mo after marsh initiation, species richness rose from about 7 species per plot to 9 to 12 species per plot, but declined during the 2 subsequent sampling dates (Fig. 4). At lower elevations richness was similar to that of the natural marsh on most dates. Exceptions were at 18 mo (planted vs natural: $t_{3}=5.422, \mathrm{p}=0.012$ ) and at $22 \mathrm{mo}$ (unplanted vs natural: $t_{3}=4.620, \mathrm{p}=0.019$ ). At upper elevations richness was lower than in the natural marsh at 6 mo (unplanted vs natural: $t_{3}=3.429, p=0.042$ i planted vs natural: $t_{3}=3.220, p=0.049$ ), 18 mo (unplanted vs natural: $\left.t_{3}=4.164, \mathrm{p}=0.025\right)$, and $22 \mathrm{mo}$ (planted vs natural: $t_{3}=4.069, \mathrm{p}=0.003$ ) (Fig. 4).

From 6 mo to 27 mo after marsh initiation, species composition in the planted and unplanted experimental plots remained fairly constant. Streblospio benedicti, Capitella spp. and turbellarians continued to account for 70 to $95 \%$ of the infauna (Fig. 5). However, a number of other taxa appeared, including terebellid, hesionid, paraonid, phyllodocid and capitellid polychaetes, tanaids, amphipods, chironomid, collembolid and odonate insects. After 18 mo oligochaetes were present at densities $\leq 3000 \mathrm{~m}^{-2}$, much lower than natural marsh oligochaete densities of 17106 to $26020 \mathrm{~m}^{-2}$ (unplanted vs natural: $t_{3}=47.666, \mathrm{p}<0.0001$; planted vs natural: $\left.t_{3}=52.514, p<0.0001\right)$.

\section{Four years: May and October 1994}

Four years after marsh establishment, macrofaunal densities in the planted treatment (spring: $11881 \pm$ $2172 \mathrm{~m}^{-2}$; fall: $26759 \pm 2869 \mathrm{~m}^{-2}$ ) remained substantially lower than densities in the natural marsh (spring: $36473 \pm 3799 \mathrm{~m}^{-2}$; fall. $63749 \pm 6528 \mathrm{~m}^{-2}$ ) (planted vs natural, spring: $t_{3}=6.170, p=0.009$; fall: $t_{3}=6.893, \mathrm{p}=0.006$ ) (Fig. 3). However, species richness was higher than that seen on previous sampling dates ( 10 to 14 species per plot), despite a $25 \%$ reduc- 
tion in area sampled. Planted marsh species richness resembled that of the natural marsh in spring, and exceeded it at lower elevations in fall $1994\left(t_{3}=8.050\right.$, $\mathrm{p}=0.001$ ) (Fig. 4).

Species composition of the planted marsh changed considerably from the previous $(27 \mathrm{mo})$ sampling period. In spring the cirratulid Aphelochaeta marioni was the most abundant polychaete (33\% of total fauna) and Streblospio benedicti was co-dominant $(29 \%$ of total fauna). Proportional representation of $S$. benedicti no longer differed in the planted and natural marsh. Many other taxa were present at low densities in 1994. including Capitella spp., Heteromastus sp., Mediomastus sp., Neanthes succinea, Nereidae, Eteone sp., Fabricia sp., an orbinid, and a paraonid polychaete as well as the gastropod Littorina irrorata and the bivalve Gemma gemma. In spring, oligochaetes were virtually absent from experimental plots (only 1 individual was collected). In fall 1994, oligochaetes were $5 \%$ of the macrofauna within the planted plots, and $57 \%$ in the natural marsh (Fig. 5).

\section{Macrofaunal feeding modes}

Representation of infaunal feeding modes was compared in the natural and man-made marshes. In upper and lower elevations of the natural marsh, surfacedeposit feeding (SDF) and subsurface-deposit feeding (SSDF) were dominant and were nearly equally represented due to the prevalence of Streblospio benedicti (SDF) and oligochaetes (SSDF) (Fig. 6). Carnivorous and omnivorous forms were less common (5 to $20 \%$ of the fauna). During the first 27 mo of the study the planted and unplanted treatments resembled one another at lower elevations, and were different from the natural marsh in that they had a lower representation of subsurface-deposit feeders (mainly due to the absence of oligochaetes) and more carnivores (Fig. 6). The proportion of subsurface-deposit feeders at lower elevations was significantly lower in the planted treatment relative to the natural marsh on 8 of 10 sampling dates (all $t_{3}>3.187, \mathrm{p}<0.050$ ) ( 1 mo and 22 mo were the exceptions) and in the unplanted treatment rela-
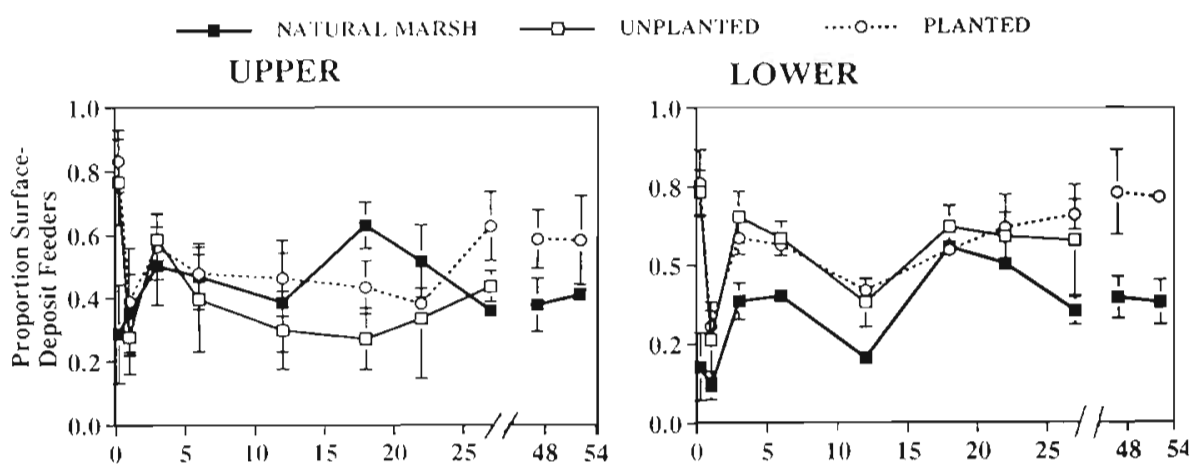

Fig. 6. Proportional representation of different macrofaunal feeding modes at upper and lower elevations in the created marsh in planted and unplanted treatments and in adjacent natural marsh plots
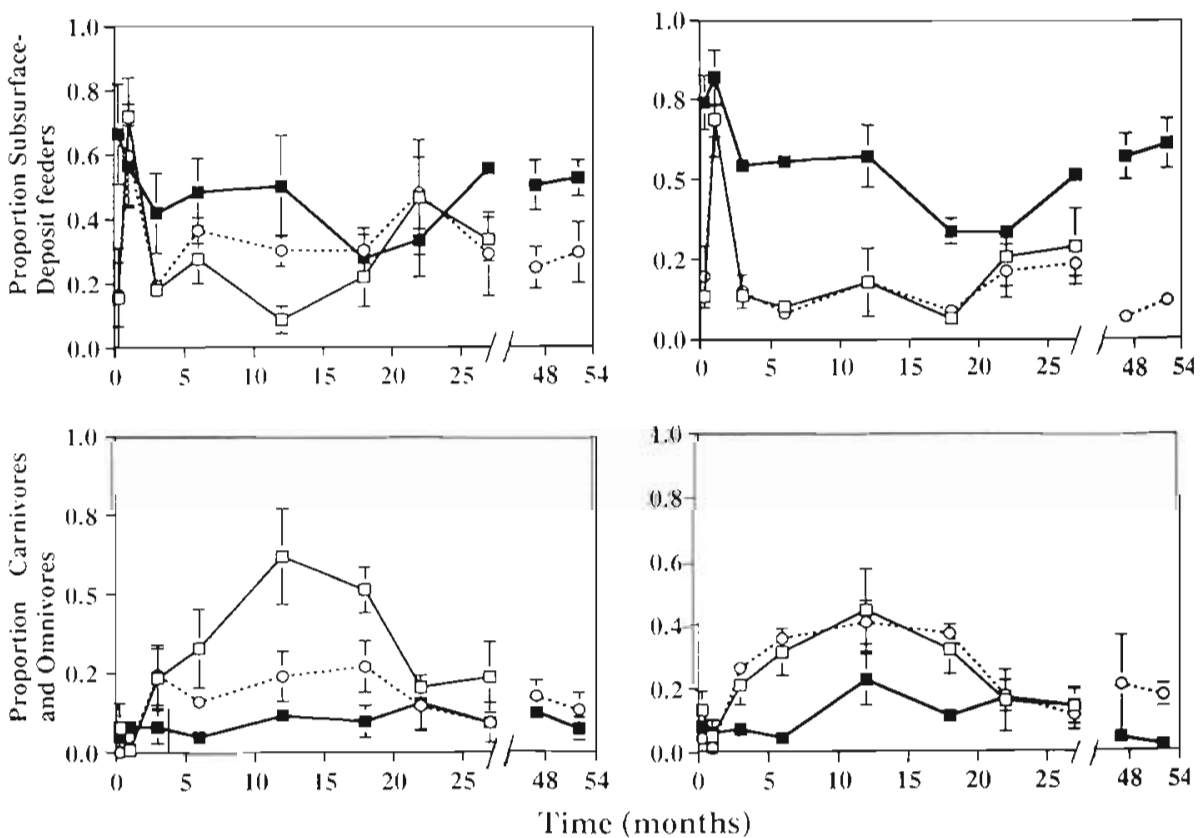
tive to the natural marsh on 4 of 8 sampling dates (1 $\mathrm{wk}, 3 \mathrm{mo}, 6 \mathrm{mo}, 18 \mathrm{mo}$; all $t_{3}>7.703, \mathrm{p}<0.005$ ). At upper elevations the lifestyle representation in the planted treatment was intermediate between that in the natural marsh, where carnivores were rare, and the unplanted treatments, where 30 to $50 \%$ of the infauna were carnivores. At upper elevations subsurfacedeposit feeders were proportionally less abundant than in the natural marsh at 3 mo only (unplanted vs natural: $t_{3}=3.966, \mathrm{p}=0.029$; planted vs natural: $t_{3}=4.118, p=0.026$ )

No differences were observed in the vertical distribution of burrowing macrofauna between the natural marsh and either of the created marsh treatments. Though the planted and unplanted plots consistently had a greater fraction of the individuals in the upper $2 \mathrm{cr}$., differences from the natural marsh were not statistically significant. Usually 70 to $95 \%$ of the macrofauna accurred in the top $2 \mathrm{~cm}$ of sediment in ali marsin treatments.

\section{Macrofaunal development modes and dispersal potential}

Streblospio benedicti produces both lecithotrophic and planktotrophic larvae in North Carolina Spartina marshes (Levin \& Huggett 1990). At least 1 species of
Capitella from elsewhere does the same (Qian \& Chia 1991). Larval type appears to be under genetic control in Streblospio (Levin et al. 1991). All brooding individuals of $S$. benedicti and Capitella spp. examined from the natural marsh had lecithotrophic larvae, and all brooding individuals observed in the created marsh had planktotrophic larvae. Based on this observation we assigned $S$. benedicti and Capitella spp. from the natural and created treatments to different reproductive categories. Oligochaetes, mainly Monopylephorus evertus, all produce cocoons and were considered direct developers with non-dispersing adult stages.

Most macrofaunal individuals in the natural marsh exhibited either direct development with a nonswimming adult stage (38 to $63 \%$ ) or produced lecithotrophic larvae ( 30 to $55 \%$ ), suggesting moderate to poor dispersal abilities. Less than $10 \%$ of the natural marsh infauna had planktotrophic larvae or swimming adiuit stages (Fig. 7).

Development-mode composition in the created marsh did not differ between vegetated and unvegetated treatments during the first 27 mo of study, but was quite distinct from the natural marsh in that most of the individuals belonged to taxa with considerable dispersal potential, i.e. those with planktotrophic larvae or swimming adults. The proportion of taxa in these 2 categories was significantly higher in unplanted and planted treatments than in the natural
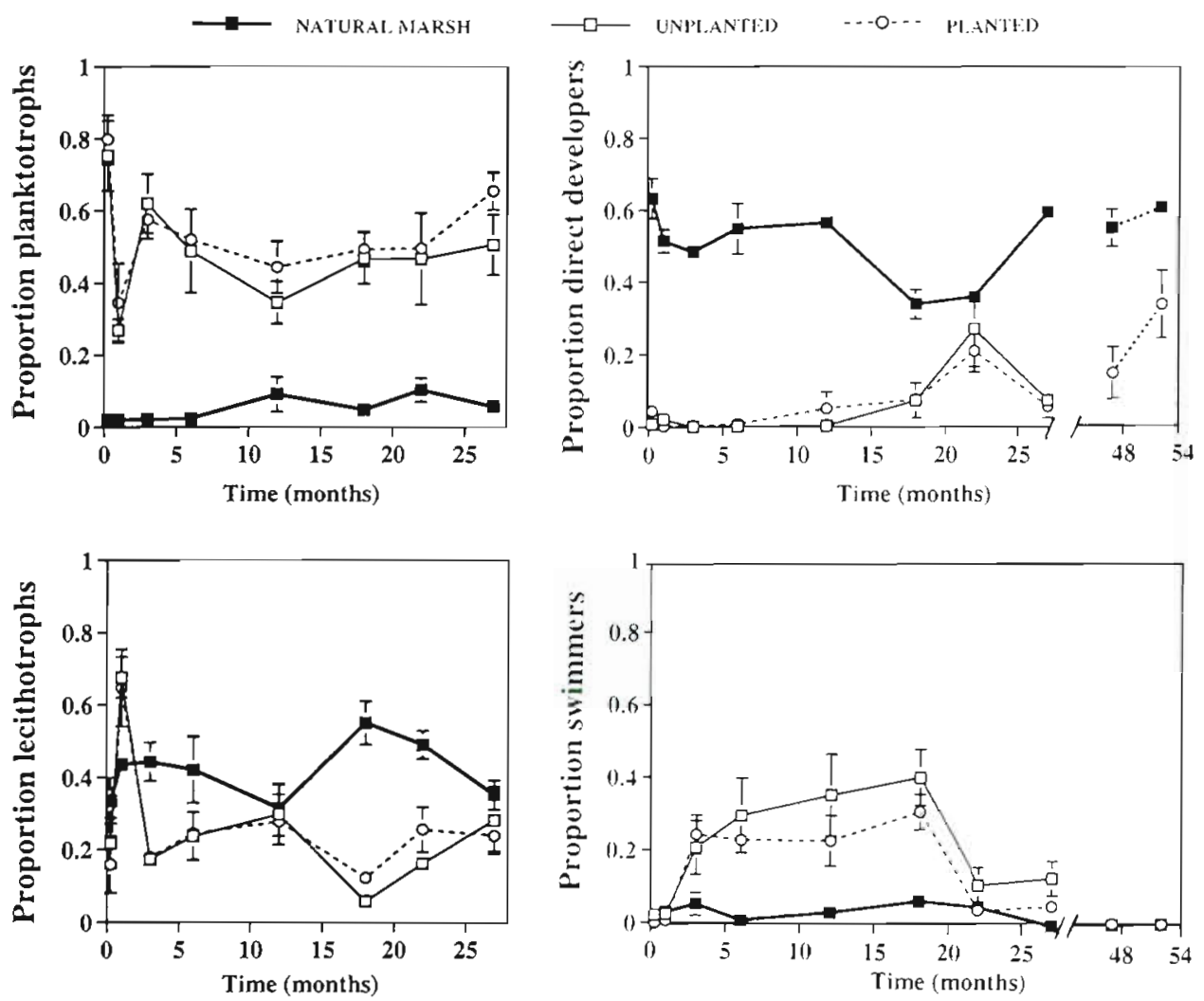

Fig. 7. Proportional representation of individuals with different developmental modes in the created marsh in planted and unplanted treatments and in adjacent natural marsh plots. Development modes are planktotrophic larval development, lecithotrophic larval development, direct development with no adult dispersal stage (direct developers), and direct development with swimming adults (swimmers) 
marsh on all sampling dates except 22 mo and 52 mo (on the other 8 dates $t_{3}>3.067 ; \mathrm{p}<0.054$ for planted and unplanted). Half or more of the colonists had planktotrophic larvae. Three to 18 mo after marsh establishment, aduit swimmers were common (20 to $40 \%$ ), while direct-developing forms were rare (Fig. 7). Development modes of taxa known to exhibit both planktotrophy and lecithotrophy (Streblospio benedicti and Capitella spp.) were not examined during Year 4, so only the proportions of species with direct development and adult swimmers were assessed for the final 2 sampling dates. On the final sampling date (52 mo), direct developers formed almost $1 / 3$ of the planted marsh macrofauna; their representation in the planted plots was not significantly different from that in the natural marsh $\left(t_{3}=2.101 ; \mathrm{p}=0.126\right)$. Increases in the densities of fabricinid polychaetes, the bivalve Gemma gemma, and tubificid oligochaetes account for much of the proportional increase in direct developers.

To determine whether the sequence of colonization by species was related to development mode we ranked sampling dates from 1 ( $1 \mathrm{wk}$ ) to 8 (27 mo) and assigned a rank to each taxon present in the created marsh based on its date of first appearance. We then divided taxa among 4 reproductive/dispersal modes (planktotrophic $n=10$ taxa, pelagic lecithotrophic $n=$ 4 , direct developers with no swimming stage $n=6$, and direct developers with an adult swimming stage $\mathrm{n}=3$ ) and calculated the mean rank of first appearance. If taxa within one development mode first appeared earlier this should be indicated by a lower rank. However, we found no statistical difference among reproductive types in timing of first appearance (Kruskal-Wallace 1-way ANOVA).

For each reproductive type we examined the percent of taxa found in the natural marsh that also appeared in the artificial marsh by Month 27 These values were 70 to $75 \%$ for taxa with planktotrophic and lecithotrophic larvae, about $66 \%$ for direct developers with swimming adults, and $50 \%$ for species with direct development.

\section{DISCUSSION}

\section{Epifaunal recovery}

Epifaunal colonization of created marsh treatments was slow and several of the major taxa present in the natural marsh failed to recruit within 27 mo of marsh creation. This occurred even though the marsh faced the Newport River estuary and had natural marshes in close proximity. In San Diego Bay, Scatolini \& Zedler (1996) found low abundances of epifauna in lower elevations of a 4 yr old created Spartina foliosa marsh rel- ative to a nearby natural marsh, based on litterbag studies. They reported that several insect, isopod and amphipod species had higher densities in the natural than created marsh, while a capitellid polychaete, the snail Assiminea californica, and a dipteran Culicoides exhibited comparable densities in the 2 systems. They also observed the crab Hemigrapsus oregonensis and the exotic mussel Musculista senhousia to persist at higher densities in the created than natural system. LaSalle et al. (1991), in a comparison of $4 \mathrm{yr}$ old and 8 yr old $S$. alterniflora marsh epifauna, observed several crab species (UCa pugnax and Sesarma reticula$t u m$ ) present only in the younger system, and several snails (Neritina usnea and Polymedosa carolineana) only at the older site. These studies, combined with our results (Table 1) suggest that burrowing fiddler and grapsid crabs are characteristic early successional fauna in created Spartina marshes, that grazing snails appear later, but that many other epifaunal forms are slow to invade the developing marsh habitat.

\section{Rates of infaunal recovery}

Recovery of macroinvertebrates following disturbance often is evaluated by assessing total macrofaunal densities and some measure of diversity (PERL 1990). Based on these measures of status, several created marshes appear to exhibit nearly complete reestablishment of macrofauna within 2 to $3 \mathrm{yr}$, at least at lower elevations (Moy \& Levin 1991, this study). However, functional equivalence between natural and created marshes, a requirement of many mitigation and restoration plans, has an additional imperative relative to macrofauna. Species composition must be similar, or functionally similar species must have replaced those originally present. In both the Port Marsh (this study) and Dills Creek Marsh (Moy \& Levin 1991), located several $\mathrm{km}$ from our study site, the rarity of the burrowing, subsurface-deposit feeding Oligochaeta, a dominant form in natural Spartina marshes throughout the USA, suggests that functional equivalence was not achieved. The absence of this group may have further ramifications relative to shellfish and finfish use. Streblospio benedicti, a tube-dwelling, surface-feeding spionid, replaced the oligochaetes, sometimes attaining densities higher than those found in the natural marsh (Moy \& Levin 1991). These trends, observed 3 to 4 yr after marsh creation in Dills Creek and the Port Marsh, probably will not persist indefinitely, but how long they will persist is unknown.

In their North Carolina studies comparing 5 created Spartina alterniflora marshes 10 to 17 yr old, each with adjacent natural marshes, Sacco et al. (1994) found oligochaete densities similar in 3 of the marsh pairs, 
higher in 1 artificial marsh, and higher in 1 natural marsh. Streblospio benedicti densities were similar in 2 of the marsh pairs, higher in 2 natural marshes and higher in 1 created marsh. Similar variability was observed in the abundance of Capitella spp. For 2 common direct developers, the sabellid Manayunkia sp. and tanaids, Sacco et al. (1994) reported densities in the created marshes lower than or equal to those in their natural counterparts. Species without planktonic dispersal stages, like oligochaetes, Manayunkia sp. and tanaids, are dominant members of natural-marsh assemblages, but can be among the slowest to recover in created marshes.

\section{Successional stages}

\section{Created marsh succession}

The faunas of fine-grained intertidal sediments, both in mudflats and salt marshes, sometimes appear to be in a perpetual state of early succession because they typically contain opportunistic species and low-diversity assemblages (Levin 1984, Moy \& Levin 1991, Trueblood et al. 1994). Large, deep-burrowing taxa characteristic of equilibrium subtidal assemblages (sensu Rhoads \& Boyer 1982) are often rare or absent. Most of the species colonizing the created Port Marsh were members of the natural marsh community, except for Aphelochaeta marioni, which appeared near the end of the study. However, several taxa attained greater proportional representation, or higher densities in the created marsh than in the natural marsh, particularly during early stages of marsh development.

Streblospio benedicti was proportionally better represented in the unplanted and planted treatments than in the natural marsh during the first year of the study, although absolute densities were often similar to those in the natural marsh (Wilcoxon signed-rank test, $p=$ 0.02). One month after marsh creation, Capitella spp. dominated the created marsh sediments, forming $70 \%$ of the infauna in the unplanted treatment, $64 \%$ in the planted treatment and only $21 \%$ in the natural marsh. However, these samples were taken in July, when the intertidal fauna is heavily stressed by high temperatures and when the natural marsh exhibited the highest Capitella spp. densities of the study period. Capitella spp. remained a larger component of the fauna in the created than natural marsh throughout the study (Fig 5), with densities in the unplanted and planted treatments exceeding those in the natural marsh on most sampling dates after July 1990. Turbellarians, though probably undersampled with a $300 \mu \mathrm{m}$ mesh, also were proportionally more common in the created than natural marsh, particularly between
Months 3 and 18. Turbellarian densities in both created treatments exceeded those in the natural marsh on 5 sampling dates. Streblospio benedicti, Capitella spp. and turbellarians accounted for 75 to $95 \%$ of the created marsh infauna for over 2 yr. Among the epifauna, fiddler crabs (UCa spp.) were the only common early colonists, exhibiting higher densities in the created than natural habitats throughout the first 2 yr of the study (Table 1).

We interpret these results to signify that a subset of the ambient marsh species are preadapted to colonizing disturbed settings, and it is these few taxa (planktotrophic forms of Streblospio benedicti, Capitella sp. and turbellarians) that form the initial successional stages. After $4 \mathrm{yr}$ the created marsh infauna had increased in species richness and evenness, but composition still differed from that of the natural marsh. Capitella spp. and $S$. benedicti were still present, but formed a lesser percent of the total tauna (23 to $55 \%$ ) than during the first 2 yr. Molluscs and fabricinid polychaetes became more common $1>25 \%$ in Oct 1994), but oligochaetes remained dramatically underrepresented.

Minello et al. (1994) compared newly established creek habitat ( 4 mo old) to 4 to 5 yr old Spartina alterniflora marsh in Texas, USA. They found higher representation of Streblospio benedicti and Capitella sp. (proportionally) in the younger creeks (58\% at lower elevation, $71 \%$ at upper elevations) than in the older, vegetated channel edge and inner marsh habitats. LaSalle et al. (1991) noted significant differences between 4 yr old and 8 yr old $S$. alterniflora habitat formed on dredge material in South Carolina, USA. Opportunistic polychaetes ( $S$. benedicti and Capitella sp.) were $13 \%$ of infauna at $4 \mathrm{yr}$ but only $0.1 \%$ at $8 \mathrm{yr}$. Oligochaetes were more common in the older system (94\% of total infauna), with 4 oligochaete species exhibiting significantly higher densities at the 8 yr old than $4 \mathrm{yr}$ old site. These studies reinforce the scenario in which Capitella spp and Streblospio benedicti are early successional marsh species that persist for several years, whereas oligochaetes characterize more mature marsh systems.

\section{Comparisons with natural systems}

There are few studies of epifaunal or macrofaunal succession in natural salt marshes, though a number of investigations have focused on meiofauna or meiofauna-macrofaunal interactions (Bell 1980, Watzin 1986). In most instances where sediments are made available for colonization in Spartina alterniflora marshes, Streblospio benedicti and turbellaria are among the first taxa to appear (Bell 1980, Watzin 1986. 
Levin \& Huggett 1990). In tidal flats and shallow subtidal sediments subject to disturbance, pioneering colonists usually include tube-building polychaetes, especially $S$. benedicti, Polydora cornuta (formerly ligni) and a capitellid (often Capitella spp. or Mediomastus spp.) (Grassle \& Grassle 1974, McCall 1977, Pearson \& Rosenberg 1978, Santos \& Simon 1980a, b, Zajac \& Whitlatch 1982, Levin 1984, Smith \& Brumsickle 1989, Trueblood et al. 1994). This seems to be true whether the disturbance is large or small. Patterns of colonization in the created Port Marsh were therefore consistent with early response to disturbance in natural soft-bottom settings. Faunal recovery (in terms of density and species composition) often occurs within weeks or months in natural, unvegetated sediments (Hall 1994), but appears to proceed much more slowly in created salt marshes (LaSalle et al. 1991, Moy \& Levin 1991. Sacco et al. 1994, Scatolini \& Zedler 1996 , this study). However, the large size of the created marshes studied, relative to those in unvegetated experiments, may be responsible for this pattern. Oligochaetes only rarely are considered in soft-bottom successional studies, but apparently some taxa can colonize small disturbances on tidal flat sediments quickly (Gallagher et al. 1983).

\section{Vegetation effects}

Early studies of salt marsh faunal distributions suggested that Spartina culms are sites of faunal aggregations (Van Dolah 1978, Rader 1984). Specific associations between fauna and above or belowground Spartina spp. biomass have been reported for a variety of infaunal taxa including oligochaetes (Healy \& Walters 1994), polychaetes (Lana \& Guiss 1992), harpacticoid copepods (Rutledge \& Fleeger 1993), and nematodes (Alkemade et al. 1992). We therefore note with interest that for the first $2 \mathrm{yr}$, the vegetated and unvegetated sediments of the created site exhibited identical patterns of macrofaunal colonization in most instances. However, we did not sample $S$. alterniflora culms directly. Because the unplanted plots and adjacent walkways were surrounded by planted $S$. alterniflora on all sides but one (the creek edge), we cannot infer that the observed successional patterns would apply to unvegetated areas larger than $6 \times 7 \mathrm{~m}$.

\section{Successional mechanisms}

A variety of factors may influence macrofaunal succession, including species-specific access to the site, habitat suitability and species interactions. We do not specifically address the latter two in this study, and acknowledge that important interactions among sediment properties, bacteria, meiofauna, macrofauna and larger predators could affect observed successional sequences.

We did compare larval development mode and dispersal potential of colonists and natural marsh fauna to test the hypothesis that these life-history traits drive (at least in part) the successional events observed. Species with planktonic larvae available at marsh inception, and with high population growth rates, were the most abundant early colonizers. Taxa lacking planktonic dispersal stages, such as oligochaetes, the bivalve Gemma gemma, and fabricinid polychaetes (Sabellidae), were slower to recover although their densities began to climb in Year 4. This is the type of colonization pattern predicted for Type II disturbances (sensu Connell \& Keough 1985, Sousa 1985), where the disturbed habitat is large and isolated from source populations. Although the natural marsh surrounds the created Port Marsh on 2 sides, dry berms separate them (Fig. 1). Thus, adults or propagules cannot swim or be advected directly between the natural and created marsh. Exchange can only occur after organisms first enter a much larger body of water, the Newport River estuary.

Patch size is known to exert influence on colonization mechanisms in varied soft-sediment habitats. Based on studies where small and large disturbances are examined, small disturbances on the scale of $\mathrm{cm}$ or $\mathrm{m}$ often are colonized by postlarvae and mobile adults, whereas planktonic larvae are a more important source of colonists for large-scale disturbances (Van Blaricom 1982, Levin 1984, Smith \& Brumsickle 1989). In both salt marsh and mudflat habitats, the majority of species often exhibit brood protection and limited dispersal ability (see Levin 1984). Both Capitella spp. and Streblospio benedicti have forms with either planktotrophic or lecithotrophic (short-lived) larvae (Levin \& Huggett 1990, Qian \& Chia 1991). The high proportion of created-marsh colonists with planktotrophic larvae in our study reflected the fact that planktotrophic forms of Capitella spp. and $S$. benedicti settled. Though the large patch size of the created marsh and its configuration probably contributed to colonization primarily via the plankton, we note that $S$. benedicti colonists are more likely to be planktotrophic than lecithotrophic larvae in small $(10 \mathrm{~cm})$ disturbances as well (Levin \& Huggett 1990). Based on our final sampling date (when direct developing Gemma gemma and fabricinid polychaetes formed $25 \%$ of the infauna), and on results in older North Carolina marshes (Sacco et al. 1994), we expect to see increased representation over time of those species with lesser dispersal ability. 
An additional explanation for slow or unsuccessful colonization of some species may be the absence of appropriate conditions following initial settlement events; recruits reaching the created marsh may not flourish. Subsurface-deposit feeders, which were less common in the created than natural marsh at low elevations throughout the study (Fig. 6), may require more organic-rich or finer sediments than were present. Oligochaetes, for example, often are associated with Spartina detritus in the sediment and aboveground (Healy \& Walters 1994, Levin unpubl. obs.). Rich belowground detritus characteristic of mature marshes was completely lacking in the Port Marsh treatments and is absent initially in many created or restored marshes unless sediments are amended with organic matter. However, experimental belowground incorporation of Spartina, peat, alfalfa and straw in this marsh failed to enhance early oligochaete recruitment or survival (L. Levin \& G. Thayer unpubl.).

\section{Implications for marsh creation}

Our results demonstrate that although vegetation can resemble the natural marsh after 3 to 4 yr (see earlier section on vegetation characteristics), the establishment of a natural infaunal assemblage in created wetlands can take more time. This is an important consideration for both scientists and managers in establishing goals and success criteria for salt marsh mitigation and restoration efforts. Similar results have been observed in other Spartina marshes for macrofauna (Moy \& Levin 1991, Sacco et al. 1994), epifauna (Zedler \& Langis 1991, Scatolini \& Zedler 1996) and fishes (Moy \& Levin 1991, Chamberlain \& Barnhart 1993). Meyer et al. (1993) showed significantly fewer total fish utilizing created marsh treatments near our sites during the first 2 yr of marsh development. However, some species of fish showed no differences in abundance. More than 13 to $16 \mathrm{yr}$ after creation, several created $S$. alterniflora marshes in North Carolina had not achieved macrofaunal densities or composition comparable to adjacent natural marshes (Sacco et al. 1994). Zedler \& Langis (1991) reported that 5 yr after restoration of a $S$. foliosa marsh in San Diego, 10 of 11 factors examined (including sediment properties, vascular plants, and epibenthic invertebrate parameters) differed from a nearby reference marsh.

Macrofaunal densities similar to natural marsh values (but with different species representation) can occur early in the development of a created marsh (e.g at 3 mo in this study), only to fall again. This result, and the failure of many marshes to achieve a species composition characteristic of natural systems, indicate that long-term monitoring is necessary to assess restoration success.

Often there is little alternative to wetlands creation or restoration. In heavily urbanized regions like California, where $>90 \%$ of the salt marsh and mudflats have disappeared (Zedler 1988), any increase in acreage must come in the form of restored or created wetlands. If succession of marsh infauna is dictated in part by species' life-history and dispersal abilities, then certain considerations might benefit infaunal establishment. Availability of recruits can be enhanced by establishing habitats during seasonal recruitment periods and by maximizing flushing and water exchange between adjacent wetlands and the estuary. Creation of contiguous borders with adjacent natural systems and intentional seeding can promote colonization by adult stages, particularly for species without planktonic stages. Attention to species requirements for sediment salinity, redox conditions, particle size, organic matter content, and detritus as food or refugia also should enhance macrofaunal success. At present we know little about the habitat preferences of most infaunal salt marsh species.

Finally, vegetation and elevation characteristics, and their relation to bird and fish predation on macrofauna, also are likely to influence infaunal development. Reduced densities of Spartina culms, limited access to created marshes, and different functional attributes of prey may influence the nature of trophic interactions in created wetlands (Moy \& Levin 1991, Chamberlain \& Barnhart 1993). Low marsh infauna appears to become established more rapidly than upper marsh infauna, perhaps due to greater encounter time with larvae and because the high marsh species are mostly direct developers with poor dispersal abilities. Thus, biasing created marshes in favor of low marsh (relative to high) could promote rapid establishment of infauna.

Acknowledgements. We thank the many people who have assisted with sampling and sorting of fauna, including D. Cabrera, C. Currin, D. Huggett, C. Huggett, C. Lund. P. Myers, G. Plaia, K Prevost, and M. LaCroix. We also thank C. Curnn and S. Broome for generously providing access to their unpublished sediment and vegetation data Two anonymous reviewers contrbuted helpful comments on an earlier version of this manuscript. This paper is funded in part by grants from the National Oceanic and Atmospheric Administration's Coastal Ocean Program and National Sea Grant College Program, under grant numbers NA26RG0474 NA36RG0469, and NA89AA-D-SG138, project numbers R/C-22-2-PT, R/C-23-3-PT, and R/CZ-125, through the Estuarine Habitat program, the Californa Sea Grant College System, and the California State Resources Agency. The views expressed herein are those of the authors and do not necessarily reflect the views of NOAA or any of its subagencies 


\section{LITERATURE CITED}

Alkemade R, Wielemaker A, Hernminga MA (1992) Stimulation of decomposition of Spartina anglica leaves by the bacterivorous marine nematode Diplolaimelloides bruciei (Monhysteridae). J Exp Mar Bıol Ecol 159:267-278

Bell SS (1980) Meiofauna-macrofauna interactions in a high salt marsh habitat. Ecol Monogr 50:487-505

Broome SW, Seneca ED, Woodhouse WW Jr (1988) Tidal salt marsh restoration. Aquat Bot 32:1-22

Cammen LM (1976) Abundance and production of macroinvertebrates from natural and artificially established salt marshes in North Carolina. Am Midl Nat 96:487-493

Chamberlain RH, Barnhart RA (1993) Early use by fish of a mitigation salt marsh, Humboldt Bay, California. Estuaries $16: 769-783$

City of Carlsbad/U.S. Army Corps of Engineers (1990) Batiquitos Lagoon enhancement project, final environmental impact report. Environmental impact statement. Carlsbad, CA

Connell JH, Keough MJ (1985) Disturbance and patch dynamics of subtidal animals on hard substrata. In: Pickett $S$, White $P$ (eds) The ecology of natural disturbance and patch dynamics. Academic Press, Inc, Orlando, p 125-151

Currin CA, Newell SY, Paerl HW (1995) The role of standing dead Spartina alterniflora and benthic microalgae in salt marsh food webs - considerations based on multiple stable isotope analysis. Mar Ecol Prog Ser 121:99-116

Fauchald K, Jumars PA (1979) The diet of worms: a study of polychaete teeding guilds. Oceanogr Mar Biol A Rev 17 : $194-284$

Gallagher ED, Jumars PA, Trueblood DD (1983) Facilitation of a soft-bottom benthic succession by tube builders. Ecology $64: 1200-1216$

Grassle JF, Grassle JP (1974) Opportunistic life histories and genetic systems in marine benthic polychaetes. J Mar Res 32:253-284

Hall SJ (1994) Physical disturbance and marine benthic communites: life in unconsolidated sediments. Oceanogr Mar Biol A Rev 32:172-239

Hall SJ, Raffaelli D, Thrush SF (1994) Patchiness and disturbance in shallow water benthic assemblages. In: Giller $P$, Hilorew A, Raffaelli D (eds) Aquatic ecology: scale, pattern and process. Blackwell Scientific Publications, London, p 333-376

Healy B, Walters K (1994) Oligochaeta in Spartina stems: the microdistribution of Enchytraeidae and Tubificidae in a salt marsh, Sapelo Island, USA. Hydrobiologia 278 : $111-123$

Lana P da Cunha, Gusss C (1992) Macrofauna-plant-biomass interactions in a euhaline salt marsh in Paranagua Bay (SE Brazil). Mar Ecol Prog Ser 80:57-64

LaSalle MW, Landin MC. Sims JG (1991) Evaluation of the flora and fauna of a Spartina alterniflora marsh established on dredged material in Winyah Bay, South Carolına. Wetlands 11:191-208

Levin LA (1984) Life history and dispersal patterns in a dense infaunal polychaete assemblage: community structure and response to disturbance. Ecology 65:1185-1200

Levin LA, Huggett DV (1990) Implications of alternative reproductive modes for seasonality and demography in an estuarne polychaete. Ecology 71:2191-2208

Levin LA, Zhu J, Creed E (1991) The genetic basis of life-history characters in a polychaete exhibiting planktotrophy and lecithotrophy. Evolution 45:380-397

McCall PL (1977) Community patterns and adaptive strategies of the infaunal benthos of Long Island Sound. J Mar Res 35:221-266
Meyer DL, Fonseca MS, Colby DR, Kenworthy WJ, Thayer GW (1993) An examination of created marsh and seagrass utilization by living marine resources. In: Magoon OT, Wilson WS, Converse H, Tobin LT (eds) Coastal Zone '93. Proc 7 th Symp Coastal Ocean Management. Am Soc Civil Engineers, New York, p 1858-1863

Minello TJ, Zimmerman RJ, Medina R (1994) The importance of edge for natant macrofauna in a created salt marsh. Wetlands 14:184-198

Moy LD, Levin LA (1991) Are Spartina marshes a replaceable resource? A functional approach to evaluation of marsh creation efforts. Estuaries 14:1-16

National Wetlands Policy Forum (NWPF) (1988) Protecting America's wetlands: an action agenda. Conservation Foundation, Washington, DC

Pearson TR, Rosenberg R (1978) Macrobenthic succession in relation to organic enrichment and pollution in the marine environment. Oceanogr Mar Biol A Rev 16:229-311

PERL (Pacific Estuarine Research Laboratory) (1990) A manual for assessing restored and natural coastal wetlands with examples from southern California. Sea Grant College Publication, La Jolla

Qian PY, Chia FS (1991) Fecundity and egg size are mediated by food quality in the polychaete worm Capitella sp. J Exp Mar Biol Ecol.148:11-25

Race MS, Christie DR (1982) Coastal zone development: mitigation, marsh creation and decision making. Environ Manage 6:317-328

Rader DN (1984) Salt marsh benthic invertebrates: smallscale patterns of distribution and abundance. Estuaries 7 . $413-420$

Rhoads DC, Boyer LF (1982) The effects of marine benthos on physical properties of sediments: a successional perspective. In: McCall PL, Tevesz MJS (eds) Animal-sediment relations. Plenum Press, New York, p 3-52

Rutledge PA, Fleeger JW (1993) Abundance and seasonality of meiofauna, including harpacticoid copepod species, associated with stems of the sait-marsh cord grass Spartina alterniflora. Estuaries 16:760-768

Sacco J, Booker F, Seneca ED (1987) Comparison of the macrofaunal communities of a human-initiated salt marsh at two and fifteen years of age. In: Zelazny J, Feierabend S (eds) Proc International Wetlands Symposium (NWF) Oct $5-10,1987$ National Wildlife Federation, Washington, DC, p 282-285

Sacco J, Seneca E, Wentworth T (1994) Infaunal community development of artificially established salt marshes in North Carolina. Estuaries 17:489-500

Santos SL, Simon JL (1980a) Marine soft-bottom community establishment following annual defaunation: larval or adult recruitment. Mar Ecol Prog Ser 2:235-241

Santos SL, Simon JL (1980b) Response of soft-bottom benthos to annual catastrophic disturbance in a south Florida estuary. Mar Ecol Prog Ser 3:347-355

Scatolini SR, Zedler JB (1996) Epibenthic invertebrates of natural and constructed marshes of San Diego Bay. Wetlands 16:24-37

Smith CR, Brumsickle SJ (1989) The effects of patch size and substrate isolation on colonization modes and rates in an intertidal sediment. Limnol Oceanogr 34:1263-1277

Sousa WP (1985) Disturbance and patch dynamics on rocky intertidal shores. In: Pickett S, White P (eds) The ecology of natural disturbance and patch dynamics. Academic Press, Inc, Orlando, p 101-124

Trueblood DD, Gallagher ED, Gould DM (1994) Three stages of seasonal succession on the Savin Hill Cove mudflat, Boston Harbor. Limnol Oceanogr 39:1440-1454 
Van Blaricom GR (1982) Experimental analysis of structural regulation in a marine sand community exposed to oceanic swell. Ecol Monogr 52:283-285

Van Dolah RF (1978) Factors regulating the distribution and population dynamics of the amphipod Gammarus palustris in an intertidal salt marsh. Ecol Monogr 48:191-217

Watzin MC (1986) Larval settlement into marne soft-sediment systems: interactions with the meiofauna. J Exp Mar Biol Ecol 98:65-113

This article was presented by K. R. Tenore (Senior Editorial Advisor), Solomons, Maryland, USA.
Zajac RN, Whitlatch RB (1982) Responses of estuarine fauna to disturbance. I. Spatial and temporal variation of infaunal recolonization. Mar Ecol Prog Ser 10:1-14

Zedler JB (1988) Salt marsh restoration: lessons from Californıa. In: Cairns J (ed) Rehabilitating damaged ecosystems. CRC Press, Boca Raton, FL, p 123-138

Zedler JB, Langis R (1991) Comparisons of constructed and natural salt marshes of San Diego Bay. Restoration Manage Notes 9:1:21-25

Manuscript first received: January 4, 1996

Revised version accepted: June 20,1996 